\title{
Studi Pendahuluan Cemaran Air Limbah Rumah Potong Hewan di Kota Mataram
}

\author{
Aini $^{1}$, Made Sriasih ${ }^{2}$, dan Djoko Kisworo ${ }^{2}$ \\ ${ }^{1}$ Magister Manajemen Sumber Daya Peternakan Universitas Mataram; e-mail: ainikesmavet@gmail.com \\ ${ }^{2}$ Fakultas Peternakan Universitas Mataram
}

\begin{abstract}
ABSTRAK
Tujuan penelitian ini adalah untuk mengetahui cemaran baku mutu air limbah Rumah Potong Hewan (RPH) Sapi dan Ayam di Kota Mataram. Semua hasil melebihi baku mutu kecuali nilai pH. Kandungan ALT rerata air limbah RPH sapi 284004 x $10^{4} \mathrm{koloni} / \mathrm{ml}$ dan mengandung mikroba jenis E.coli dan Salmonella. Sedangkan air limbah RPH ayam ALT rerata $101596 \times 10^{5} \mathrm{koloni} / \mathrm{ml}$ dan mengandung kuman jenis E. coli, Pseudomonas aeruginosa dan Klebsiella pneumoniae. Tingginya kandungan BOD, COD, TSS, ammonia, $\mathrm{pH}$, minyak dan lemak maupun cemaran mikroba diduga disebabkan tidak difungsikannya Instalasi Pengolahan Limbah (IPAL) pada RPH sapi dan tidak optimalnya fungsi IPAL di RPH ayam.
\end{abstract}

Kata kunci: RPH sapi, RPH ayam, Baku mutu limbah RPH, Cemaran mikroba, kota Mataram

\begin{abstract}
The purpose of this study was to determine the contamination of waste water quality standard and microbiologic contamination ofcattle and chicken slaughterhousein Mataram city. TPC average content of waste water of cattle slaughterhouse was $284004 \times 10^{4}$ colonies/ ml, and contained microbial species of E. coli and Salmonella. However, the TPC avarange of wastewater of chicken slaughterhouse accounted for $101596 \times 10^{5}$ colonies/ml and contained microbial species of E. coli, Pseudomonas aeruginosa and Klebsiella pneumoniae. High content of BOD, COD, TSS, ammonia, $\mathrm{pH}$, oil and fats as well as microbial contamination may relate to disfunctionality of Waste Water Treatment Installation (IPAL) in cattle slaughterhouse and too less optimum function of the IPAL in chicken slaughterhouse.
\end{abstract}

Keywords: cattle slaughter house, chicken slaughter house, slaughterhouse waste quality standard, microbial contamination, Mataram city

Citation: Aini, A., Sriasih, M, dan Kisworo, D. (2017). Studi Pendahuluan Cemaran Air Limbah Rumah Potong Hewan di Kota Mataram. Jurnal Ilmu Lingkungan, 15(1), 42-48, doi:10.14710/jil.15.1.42-48

\section{Pendahuluan}

Untuk memenuhi kebutuhan daging yang Aman, Sehat Utuh dan Halal (ASUH) maka pemotongan harus dilakukan di Rumah Potong Hewan (RPH). Salah satu persyaratan teknis yang diatur dalam Permentan No. 13/Permentan/OT.140/1/2010 tentang persyaratan rumah potong hewan ruminansia dan unit penanganan daging (meat cutting plant) adalah, bahwa lokasi rumah potong hewan tidak menimbulkan gangguan dan pencemaran lingkungan.

Provinsi Nusa Tenggara Barat memiliki 34 unit RPH dan 25 unit Tempat Pemotongan Hewan (TPH) yang tersebar di sepuluh Kabupaten/Kota (Dinas Peternakan dan Kesehatan Hewan, 2014). Total pemotongan sapi yang tercatat di Provinsi Nusa Tanggara Barat pada tahun 2014 sebanyak 46.593 ekor dan total pemotongan di Kota Mataram adalah 16,02\% (7.465 ekor) dari total pemotongan NTB.

Kota Mataram memiliki 3 unit RPH yaitu RPH sapi, RPH Babi dan RPH Ayam. RPH sapi terletak di jalan Transito Majeluk Transito No. 17 Kelurahan Majeluk Kecamatan Cakranegara. Pada RPH sapi aliran drainase RPH berasal dari air sungai yang dialirkan ke sekeliling area RPH sehingga semua limbah yang berasal dari aktivitas RPH mengalir melalui drainase. Jumlah petugas sebanyak sepuluh orang. Kegiatan operasional RPH dimulai pukul 04.00 s/d 07.00 dengan jumlah pemotongan rata-rata 20 ekor per hari. RPH ayam terletak di Kecamatan Pagesangan, didirikan pada tahun 2010. Jumlah pemotongan setiap hari sekitar 150-200 ekor. Hal tersebut berkontribusi pada tingkat cemaran limbah cair RPH.

Limbah cair RPH mengandung larutan darah, protein, lemak dan padatan tersuspensi yang menyebabkan tingginya bahan organik dan nutrisi, tingginya variasi jenis dan residu yang terlarut ini akan memberikan efek mencemari sungai dan badan air (Kundu et al., 2013). Limbah cair yang dikeluarkan oleh RPH harus dilakukan pengolahan sebelum 
dibuang ke lingkungan agar cemaran tidak melebihi baku mutu air limbah. Baku mutu air limbah bagi usaha dan atau kegiatan RPH berdasarkan Peraturan Menteri Lingkungan Hidup No. 5 Tahun 2014 di antaranya limbah cair memiliki kadar paling tinggi untuk BOD $100 \mathrm{mg} / \mathrm{l}$, COD $200 \mathrm{mg} / \mathrm{l}$, TSS $100 \mathrm{mg} / \mathrm{l}$, minyak dan lemak 15mg/l, NH3-N 25 mg/l dan pH 69 (Kementerian Lingkungan Hidup, 2014). Selain itu dengan menentukan kandungan dalam limbah dapat ditentukan proses pengolahan limbah yang dibutuhkan (Herlambang, 2006). Salah satu penelitian terbaru yang mengolah air limbah secara elektrokoagulasi dilakukan oleh Kobya et al. (2006) menunjukkan bahwa efisiensi penyisihan COD (Chemical Oxygen Demand) 93\%.

Selain kandungan kimia sesuai baku mutu pada limbah rumah potong hewan juga terkandung mikroba. Mikroba ini berasal dari feses, urine, isi rumen, atau isi lambung, darah, daging atau lemak. Hasil isolasi yang dilakukan, mikroba yang terkandung dalam limbah cair RPH ayam di antaranya adalah Bacillus subtilis, Bacillus thuringiensis, dan Lysinibacillus fusiformis (Tantrip dan Thungkao, 2011). Bahaya atau risiko yang ditimbulkan sebagai akibat dari aktivitas di RPH yang pengelolaan air limbahnya kurang sempurna atau tidak adanya instalasi pengolahan air limbah (IPAL) memiliki potensi bahaya, di antaranya adanya bakteri-bakteri patogen penyebab penyakit, meningkatnya kadar BOD, COD, TSS, minyak dan lemak, pH dan NH3-N. Berdasarkan hal tersebut maka perlu dilakukan penelitian mengenai tingkat cemaran baku mutu air limbah RPH sapi dan ayam di Kota Mataram.

\section{Metode Penelitian}

Penelitian ini dilaksanakan di RPH Sapi dan RPH ayam di Kota Mataram, selama 4 bulan, dimulai dari bulan April 2015 sampai dengan Juli 2015. Analisis laboratorium dilakukan di Balai Laboratorium Kesehatan Masyarakat Pulau Lombok (BLKMP). Data awal diperoleh dengan melakukan survei pada RPH sapi dan RPH ayam di Kota Mataram, untuk mengetahui kondisi di RPH dengan melihat langsung (observasi) dan melakukan wawancara dengan petugas RPH. Untuk pengujian fisika-kimia contoh air sebanyak 1 liter diambil dari aliran limbah cair di 2 (dua) rumah potong hewan di Kota Mataram. Untuk analisis mikrobiologi contoh air diambil sebanyak 0,5 liter dengan menggunakan botol steril secara aseptik. Pengambilan sampel dilakukan secara purposive sampling pada saat pemotongan sedang berlangsung. Pengambilan sampel di RPH sapi dilakukan pada hari Sabtu dengan jumlah pemotongan ternak yakni 18-20 ekor dan untuk RPH ayam dilaksanakan pada hari biasa dengan jumlah pemotongan rata-rata sebanyak 150-200 ekor per hari. Pengambilan sampel di masing-masing lokasi RPH dilakukan dengan 5 (lima) kali ulangan dengan kode R1-R5, dan setiap ulangan diambil dari lima titik pengambilan yang dicampur dalam waktu yang sama. Analisis data dilakukan secara deskriptif yaitu dengan membandingkan hasil yang diperoleh dengan baku mutu yang telah ditetapkan.

\section{Hasil dan Pembahasan}

\subsection{Hasil Pengujian Air Limbah Sesuai Baku Mutu}

Air limbah RPH sapi dan RPH ayam (Tabel 1 dan Tabel 2) dalam penelitian ini diuji berdasarkan Peraturan Menteri Lingkungan Hidup No. 5 Tahun 2014 tentang baku mutu air limbah dengan parameter yang diamati adalah BOD, COD, TSS, pH, ammonia, minyak dan lemak. Sampel dikoleksi sebanyak 5 kali dengan interval pengambilan sampel satu minggu dengan diberi kode R1-R5, dan hasil penelitian di kedua sekolah ditunjukkan Gambar 1.

Tabel 1. Hasil Pengujian Air Limbah RPH Sapi

\begin{tabular}{|c|c|c|c|c|c|c|c|c|}
\hline \multirow{2}{*}{ Parameter } & \multicolumn{5}{|c|}{ Sampel } & \multirow{2}{*}{ Total } & \multirow{2}{*}{ Rerata } & \multirow{2}{*}{ Baku Mutu } \\
\hline & $\mathrm{R} 1$ & $\mathrm{R} 2$ & R3 & $\mathrm{R} 4$ & R5 & & & \\
\hline $\mathrm{BOD}(\mathrm{mg} / \mathrm{l})$ & 2470 & 2430 & 1600 & 388 & 368 & 7256 & $1451,20 \pm 1039,45$ & 100 \\
\hline $\mathrm{COD}(\mathrm{mg} / \mathrm{l})$ & 2700 & 3650 & 1962 & 585 & 414 & 9311 & $1862,20 \pm 1381,72$ & 200 \\
\hline $\mathrm{TSS}(\mathrm{mg} / \mathrm{l})$ & 220 & 1060 & 750 & 520 & 510 & 3060 & $612,00 \pm 313,16$ & 100 \\
\hline Minyak\&lemak (mg/l) & 102 & 64 & 162 & 8 & 36,4 & 372,4 & $74,48 \pm 59,99$ & 15 \\
\hline $\mathrm{NH}_{3} \mathrm{~N}(\mathrm{mg} / \mathrm{l})$ & 12.3 & 54.9 & 36.0 & 24.0 & 15 & 142,2 & $28,44 \pm 17,45$ & 25 \\
\hline $\mathrm{pH}$ & 9.5 & 6 & 6.0 & 6.5 & 5 & 33 & $6,60 \pm 1,71$ & $6-9$ \\
\hline
\end{tabular}

Tabel 2. Hasil Pengujian Air Limbah RPH Ayam

\begin{tabular}{|c|c|c|c|c|c|c|c|c|}
\hline \multirow{2}{*}{ Parameter } & \multicolumn{5}{|c|}{ Sampel } & \multirow{2}{*}{ Total } & \multirow{2}{*}{ Rerata } & \multirow{2}{*}{$\begin{array}{l}\text { Baku } \\
\text { Mutu }\end{array}$} \\
\hline & $\mathrm{R} 1$ & $\mathrm{R} 2$ & R3 & R4 & R5 & & & \\
\hline$\overline{\mathrm{BOD}(\mathrm{mg} / \mathrm{l})}$ & 10850 & 4300 & 2980 & 838 & 1245 & 20213 & $4042,60 \pm 4050,68$ & 100 \\
\hline $\mathrm{COD}(\mathrm{mg} / \mathrm{l})$ & 13000 & 5025 & 3338 & 1160 & 2300 & 24823 & $4964,60 \pm 4711,48$ & 200 \\
\hline $\mathrm{TSS}(\mathrm{mg} / \mathrm{l})$ & 280 & 1110 & 3340 & 738 & 3585 & 9053 & $11810,60 \pm 1538,80$ & 100 \\
\hline Minyak\&lemak(mg/l) & 112 & 38 & 200 & 30 & 174 & 554 & $110,80 \pm 77,11$ & 15 \\
\hline $\mathrm{NH}_{3} \mathrm{~N}(\mathrm{mg} / \mathrm{l})$ & 185 & 315 & 292 & 275 & 266 & 1333 & $266,60 \pm 49,29$ & 24 \\
\hline $\mathrm{pH}$ & 9.0 & 6.0 & 6.5 & 6 & 6 & 33,5 & $6,70 \pm 1,30$ & $6-9$ \\
\hline
\end{tabular}

Sumber data diolah dari hasil uji BLKMP 


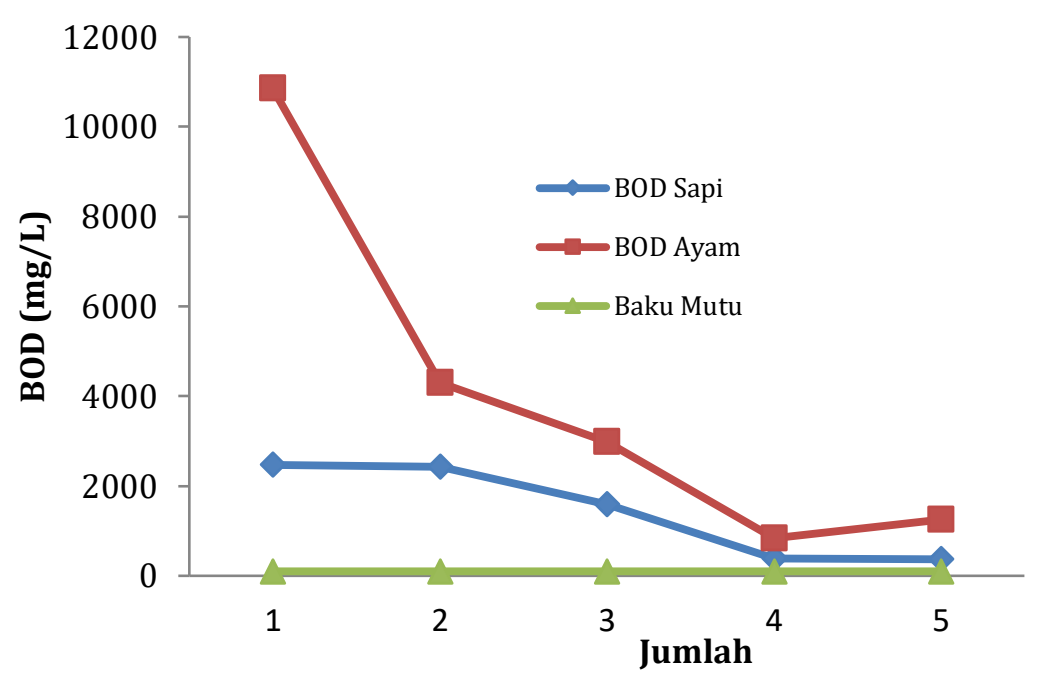

Gambar 1 Kadar BOD air limbah RPH

Kadar BOD rata-rata pada (Gambar 1) RPH ayam 14 kali lipat dari baku mutu dan pada RPH sapi kadar BOD sekitar 40 kali lipat dari baku mutu. Effendi (2003) menyatakan bahwa semakin besar BOD di dalam air menunjukkan semakin besar pula kandungan bahan organik. Hasil studi lain menunjukkan bahwa tingginya zat organik dalam air dapat diturunkan dengan beberapa teknik atau metode. Salah satu alternatif yang dapat dilakukan adalah dengan menggunakan biofilter. Penelitian yang dilakukan oleh Susanto et al. (2013) merupakan salah satu alternatif cara yang bisa dilakukan untuk menurunkan kadar zat organik dengan menggunakan biofilter kombinasi anaerob-aerob yang telah mampu menurunkan kadar BOD sekitar 72,56-91,65\% dari $1198,5 \mathrm{mg} / \mathrm{l}$ menjadi 782,6 mg/l. Penelitian yang dilakukan oleh Susanto et al. (2013) menurunkan kadar BOD air limbah RPH dengan melewatkan air limbah pada media botol plastik yang berfungsi sebagai tempat melekatnya mikroba aerob dan anaerob dan membentuk biofilter yang mampu menurunkan kadar BOD.

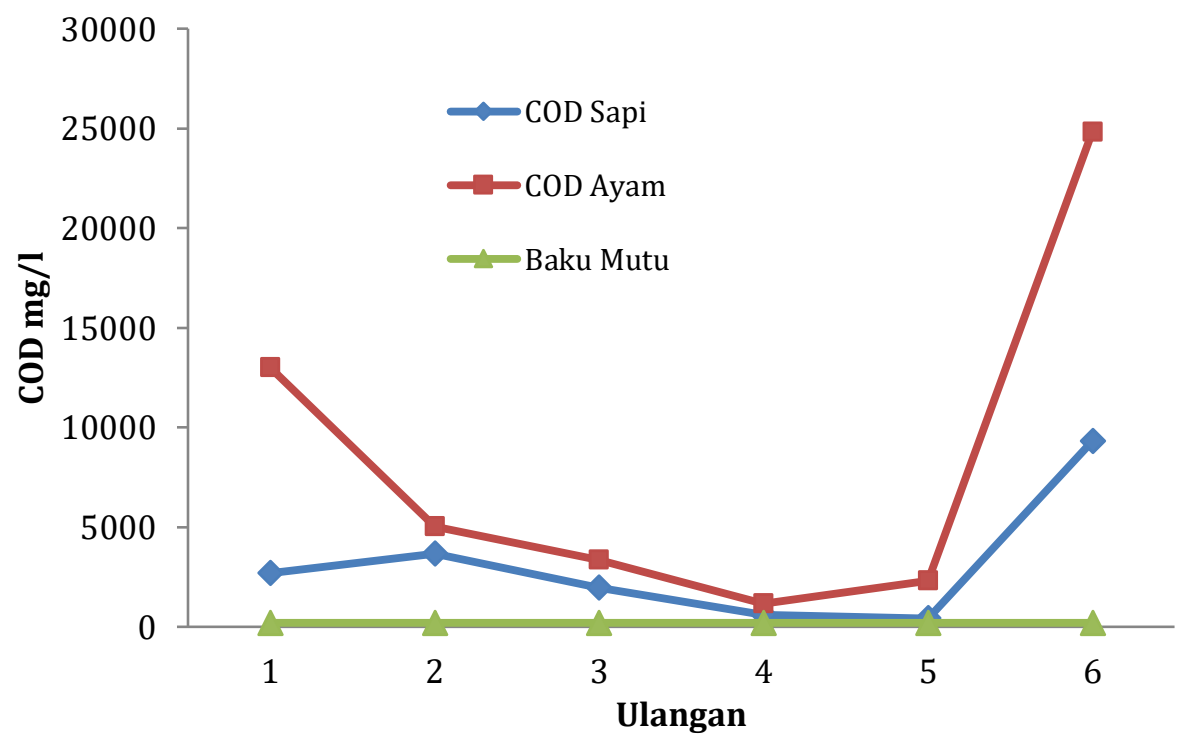

Gambar 2. Kadar COD air limbah RPH

Kadar rata-rata COD (Gambar 2) pada RPH ayam menunjukkan nilai 4964,4 mg/l yaitu sekitar 20 kali lipat lebih tinggi dari baku mutu. Pada RPH sapi nilai rata-rata COD adalah $1862,2 \mathrm{mg} / \mathrm{l}$ atau sekitar 9 kali lipat lebih tinggi dibandingkan dengan baku 44 mutu. Tingginya kadar COD menunjukkan tingginya jumlah oksigen yang dibutuhkan untuk mengoksidasi seluruh bahan kimia baik organik maupun anorganik di dalam sampel air limbah. Hasil penelitian ini lebih tinggi dari penelitian yang dihasilkan oleh Widya et al. 
(2009) untuk RPH sapi , RPH babi dan RPH ayam sebesar 689,75 mg/l, 603,25 mg/l dan $580 \mathrm{mg} / \mathrm{l} \mathrm{hal}$ ini disebabkan karena penelitian yang dilakukan oleh Widya et al. (2009) terhadap air limbah di Desa Darmasaba terhadap limbah pemotongan sapi, babi dan ayam masih dalam skala kecil (rumah tangga) dan sistem pemotongannya dilakukan secara tradisional (manual) akan tetapi tidak ada penjelasan mengenai jumlah pemotongan.

Kadar COD dan BOD yang tinggi jika dibuang langsung ke lingkungan akan melebihi kemampuan asimilasi di dalam aliran air maka bakteri akan tumbuh dengan cepat dan mengkonsumsi semua oksigen terlarut dan akibatnya akan tercipta kondisi anaerobik. Pengurasan oksigen terlarut dan pertumbuhan bakteri yang berlebihan mengakibatkan lenyapnya protozoa dan ikan
(Triatmojo et al. 2008). Salah satu indikator untuk melihat dampak adanya zat organik dalam air limbah adalah rasio BOD/COD. Rasio BOD/COD didapat dengan membagi konsentrasi BOD dan konsentrasi COD (Putri et al. 2013). Data pada Tabel 1 dan 2 diperoleh rasio $\mathrm{BOD} / \mathrm{COD}$ dengan nilai 0,77 untuk RPH sapi dan rasio BOD/COD air limbah RPH ayam adalah 0,81. Penelitian yang dilakukan oleh Parasmita et al. (2012) dapat dijadikan sebagai salah satu alternatif untuk menurunkan bahan pencemar secara biologis dengan menggunakan mikroba yang dilekatkan pada kerikil sehingga membentuk biofilter pada kondisi aerob dan anaerob untuk menurunkan BOD, COD dan TSS pada air lindi dan diperoleh hasil yang mampu menurunkan kandungan BOD hingga $65 \%$ dan menurunkan kandungan COD hingga $29,21 \%$.

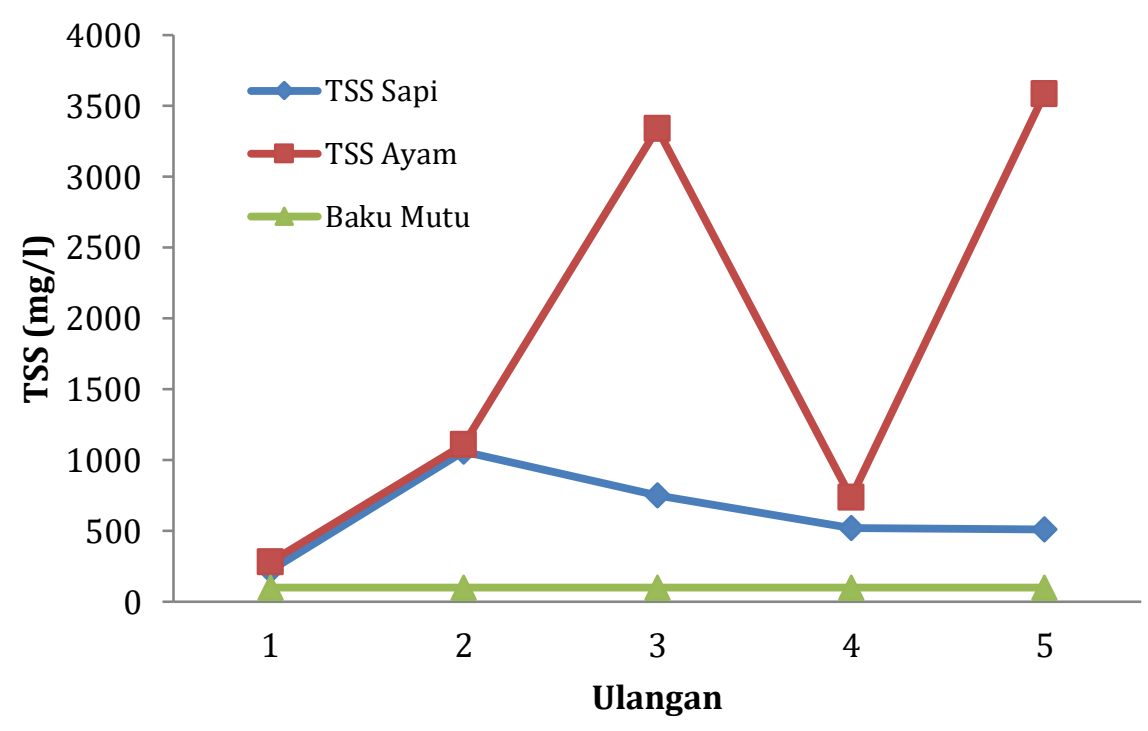

Gambar 3. Kadar TSS air limbah RPH

TSS pada air limbah (Gambar 3) RPH sapi rata-rata mencapai $612 \mathrm{mg} / \mathrm{l}$ dan pada air limbah RPH ayam 1810,6 mg/l. Tingginya kadar TSS pada air limbah RPH ayam jika dibandingkan dengan pada air limbah RPH sapi disebabkan pada aliran IPAL air limbah RPH ayam tidak pengalami pengenceran seperti pada RPH sapi. Kadar TSS yang tinggi akan menimbulkan pencemaran perairan. Tingginya kadar TSS yang melebihi baku mutu pada semua jenis air limbah diduga akibat kotoran isi rumen, isi lambung, isi usus, darah dan bahan lainya. Keadaaan ini tampak pada air limbah RPH sapi berwarna coklat sampai merah tua serta mengeluarkan bau amis sampai bau busuk.

Pengujian air limbah RPH sapi dan ayam menunjukkan bahwa air limbah tersebut mempunyai kisaran pH yang optimum bagi pertumbuhan bakteri sehingga tidak mengganggu proses pengolahan. Nilai
pH pada air limbah ini sama dengan hasil penelitian yang dilakukan oleh Suardana (2007) dengan hasil 6,97 untuk air limbah RPH sapi dan babi di Pesanggrahan walaupun jumlah pemotongan yang dilakukan pada RPH Pesanggrahan lebih banyak dengan rata-rata jumlah pemotongan sekitar 38 ekor sapi dan 114 ekor babi per hari. Widya et al. (2009) dalam penelitiannya juga menunjukkan $\mathrm{pH}$ normal terhadap air limbah di desa Abiansemal Badung pada rumah potong sapi, babi dan ayam.

Rata-rata kadar minyak dan lemak pada air limbah RPH sapi adalah 74,48 mg/l dan RPH ayam sebesar $110,8 \mathrm{mg} / \mathrm{l}$. Kadar minyak dan lemak pada RPH sapi tidak merata antar ulangan meskipun melebihi baku mutu. Hal ini diduga disebabkan karena kebiasaan pengguna RPH yang membuang bagian lemak pada saat membersihkan bagian dalam rumen dengan 
jumlah dan frekuesi waktu yang berbeda pada setiap ulangan ke aliran air limbah.Hasil penelitian ini lebih rendah dibandingkan dengan penelitian yang dilakukan oleh Roniadiet al. (2013) dengan hasil 170 $\mathrm{mg} / \mathrm{L}$ dimana hasil minyak dan lemak melebihi baku mutu yang dipersyaratkan akan tetapi jumlah pemotongan tidak dicantumkan. Salah satu alternatif untuk menurunkan nilai minyak dan lemak pada RPH adalah dengan memanfatkan mikroba yang didapat dengan mengisolasi mikroba pendegradasi lemak pada limbah RPH dapat digunakan untuk menguraikan minyak dan lemak yang ada pada limbah RPH. Bakteri pendegradasi lemak bekerja untuk menguraikan minyak dan lemak dalam limbah dengan efektif dan tidak menghasilkan racun atau blooming karena mikroba ini akan mati seiring dengan habisnya minyak. Seperti penelitian yang dilakukan oleh Darmayasa (2008) telah berhasil mengisolasi bakteri pendegradasi lipid (lemak) dari RPH di Pesanggrahan dengan jenis Klebsiella yang sangat mungkin untuk dicoba mengenai kemampuannya dalam mendegradasi lemak dari limbah rumah potong.

Kadar ammonia pada air limbah RPH sapi dan ayam menunjukkan nilai yang melebihi baku mutu yaitu sebesar 28,44 mg/l Hasil penelitian ini lebih tinggi dari penelitian yang dilakukan oleh Widya et al. (2009) dengan kadar ammonia sebesar 28,40 mg/l untuk air limbah RPH sapi dan 58,98 mg/l untuk air limbah RPH ayam. Hal ini diduga disebabkan karena kadar ammonia pada limbah sapi sudah mengalami pengenceran oleh air sungai yang berfungsi sebagai pengencer limbah RPH. Kadar ammonia yang tinggi pada limbah RPH ayam disebabkan oleh terjadinya NO3 akibat proses nitrifikasi dari ammonia dari air limbah yang mengandung nitrat tinggi, yang bila disalurkan ke suatu perairan akan dapat membahayakan kehidupan akuatik (Alaerts dan Santika, 1984 dalam Widya et al. 2009). Tingginya kadar ammonia pada limbah RPH ayam dibandingkan dengan RPH sapi diduga disebabkan oleh kandungan protein dalam ransum yang diberikan pada ayam broiler akhir berkisar antara 18-20,5\% (Amrullah,
2002) dan lebih tinggi dibandingkan dengan ransum sapi bobot badan 300-400 kg kandungan protein berkisar antara 8,5- 10,5\% (Parakkasi, 1999).

Secara keseluruhan dari data yang ada pada Tabel 1 dan 2 menunjukkan bahwa berdasarkan peraturan Menteri Lingkungan Hidup No. 5 Tahun 2014 tentang baku mutu air limbah bagi kegiatan RPH, kualitas BOD, COD, TSS, ammonia, minyak \& lemak dari RPH sapi dan RPH ayam berada diatas baku mutu. Nilai pH sudah memenuhi baku mutu yang ditetapkan. Hasil pengukuran air limbah RPH sapi dan RPH ayam dimungkinkan untuk dilakukan pengolahan secara biologis berdasarkan rasio BOD/COD yang didapat yaitu sebesar 0,77 untuk RPH sapi dan 0,88 untuk RPH ayam dan ditunjang dengan nilai pH yang optimum untuk pertumbuhan bakteri. Hasil penelitian ini berbeda dengan hasil penelitian yang dilakukan oleh Roniadi et al. (2013) terhadap limbah rumah potong di Kelurahan Mabar Hilir Kecamatan Medan Deli, pada penelitian tersebut hasil yang didapat bahwa parameter BOD, TSS, NH3N dan pH sudah memenuhi seluruh standar pada baku mutu sedangkan kualitas COD, minyak dan lemak masih berada diatas ambang batas standar yang ditetapkan. Perbedaan hasil ini kemungkinan disebabkan oleh RPH Medan Deli mempunyai unit pengolahan IPAL yang dilengkapi dengan kolam limbah padat, limbah cair dan kolam oksidasi dan masing- masing limbah yang melewati kolam mempunyai masa tinggal yang berbeda dan volume kolam sudah sesuai dengan debit limbah yang dihasilkan. Pada bagian akhir kolam oksidasi ditanami enceng gondok sebelum dibuang ke lingkungan yang berfungsi untuk meningkatkan kandungan oksigen terlarut. Penelitian lain yang dilakukan oleh Bazrafshan et al. (2012) terhadap limbah RPH di Iran dengan jumlah pemotongan 250 ekor/hari, pada tahap pertama pengolahan air limbah tanpa penambahan bahan kimia (hanya pengolahan alami) akan tetapi diberikan waktu tinggal selama 24 jam ternyata efektif untuk menurunkan kadar BOD, COD, TSS, TKN, dengan penurunan mencapai $14 \%$, 29\%, 64\% dan 33\%.

Tabel 3. Hasil Uji Mikrobiologi RPH sapi

\begin{tabular}{llllll}
\hline \hline \multirow{2}{*}{ Parameter } & \multicolumn{5}{c}{ Ulangan } \\
\cline { 2 - 6 } & $\mathrm{R} 1$ & $\mathrm{R} 2$ & $\mathrm{R} 3$ & $\mathrm{R} 4$ & $\mathrm{R} 5$ \\
\hline ALT (koloni/ml) & $2 \times 10^{5}$ & $57 \times 10^{7}$ & $43 \times 10^{7}$ & $32 \times 10^{8}$ & $100 \times 10^{8}$ \\
E. coli & positif & positif & positif & positif & negatif \\
Salmonella & positif & negatif & negatif & negatif & negatif \\
Pseudomonas aeruginosa & negatif & negatif & negatif & negatif & negatif \\
Klebsiella pneumoniae & negatif & negatif & negatif & negatif & negatif \\
\hline Sumber data diolah dari hasil uji BLKMP & & & & &
\end{tabular}

Tabel 4. Hasil uji mikrobiologi RPH ayam

\begin{tabular}{llllll}
\hline \multirow{2}{*}{ Parameter } & \multicolumn{5}{c}{ Ulangan } \\
\cline { 2 - 6 } & $\mathrm{R} 1$ & $\mathrm{R} 2$ & $\mathrm{R} 3$ & $\mathrm{R} 4$ & $\mathrm{R} 5$ \\
\hline ALT (koloni/ml) & $60 \times 10^{8}$ & $436 \times 10^{7}$ & $38 \times 10^{6}$ & $31 \times 10^{9}$ & $94 \times 10^{8}$ \\
E. coli & positif & Negatif & negatif & positif & positif \\
Salmonella & negatif & Negatif & negatif & negatif & negatif \\
Pseudomonas aeruginosa & positif & Negatif & negatif & negatif & negatif \\
Klebsiella pneumoniae & negatif & Positif & negatif & negatif & negatif \\
\hline Sumber data diolah dari
\end{tabular}




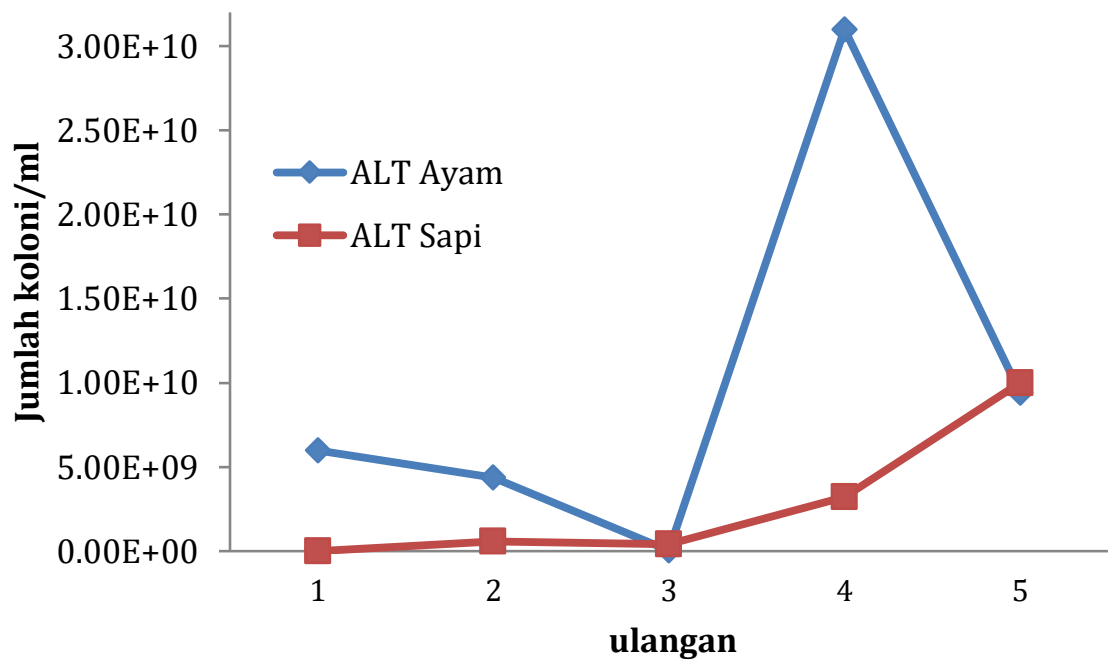

Gambar 4. Hasil pengujian ALT air limbah RPH sapi

Gambaran ALT (Gambar 4) pada limbah pemotongan ayam lebih tinggi dibandingkan dengan RPH limbah pemotongan sapi hal ini disebabkan karena pada limbah RPH sapi telah mengalami pengenceran oleh aliran air drainase di sekeliling RPH sapi. Pada RPH ayam ALT masih tinggi meskipun sudah dialirkan melalui IPAL. Tingginya ALT pada air limbah RPH sapi dan RPH ayam memungkinkan untuk dilakukannya pengolahan dengan memanfaatkan ALT dalam air limbah seperti penelitian yang dilakukan oleh Said dan Satmoko (2006) yaitu dengan menggunakan proses biofilter kombinasi anaerob aerob. Selain itu menurut Susanto et al. (2012) mikroba merupakan salah satu kunci untuk ikut menentukan berhasil tidaknya penanganan limbah secara biologi karena keberadaan mikroba sangat diperlukan untuk berbagai tahapan dalam perombakan bahan organik.

E.coli terdapat pada air limbah RPH sapi di semua ulangan. Pada RPH ayam E. coli positif sebanyak tiga kali ulangan (pada ulangan ke 1, 4 dan 5) dan dua kali ulangan negatif. Samonella positif pada air limbah RPH sapi (satu) kali ulangan dan pada RPH ayam didapat hasil negatif pada semua ulangan. Adanya E. coli pada air limbah RPH ini disebabkan oleh buangan pada limbah berasal dari kotoran hewan yang ikut mengalir di aliran limbah. Bakteri E. coli merupakan bakteri yang memiliki habitat normal di usus manusia dan hewan, karena itulah bakteri coliform terutama E. coli menjadi petunjuk dari pencemaran fecal (Arnia dan Warganegara, 2012). Salmonella pada aliran limbah RPH sapi akan memberikan dampak pada pencemaran lingkungan karena air merupakan sumber penularan Salmonella typhi yang mempunyai patogenitas untuk menimbulkan diare, demam tifoid dan bakterimia (Syahrurachman et al. 1994).

Hasil uji Pseudomonas aeruginosa menunjukkan hasil negatif pada limbah RPH sapi pada semua ulangan dan satu kali ulangan positif pada limbah RPH ayam. Klebsiella pneumoniae tidak ditemukan pada air limbah RPH sapi, dan pada RPH ayam Klebsiella pneumoniae ditemukan 1 kali uji positif.Pseudomonas aeroginosa merupakan mikroba yang menyebabkan infeksi pada saluran pernafasan bagian bawah, saluran kemih, mata dan lainya (Syahrurachmanet al. 1994). Klesiella pneumoniae merupakan penghuni normal traktus digestivus, kuman ini dapat diisolasi dari tinja manusia dan hewan.

Secara keseluruhan dari hasil uji mikrobiologi yang dilakukan bahwa air limbah RPH sapi dengan ALT rerata hasil 284.004 x 104 koloni/ml dan mengandung mikroba dengan jenis E.coli dan Salmonella. Pada limbah RPH ayam kandungan ALT rerata 101596 x 105 koloni/ml dan mengandung kuman dengan jenis E.coli, Pseudomos aeruginosa dan Klebsiella pneumoniae.

\section{Kesimpulan}

Berdasarkan hasil dan pembahasan penelitian yang telah dilakukan dapat disimpulkan sebagai berikut :

- Kadar BOD, COD, TSS, minyak dan lemak serta ammonia pada air limbah RPH sapi dan ayam berada di atas baku mutu sedangkan parameter $\mathrm{pH}$ masih berada dalam baku mutu air limbah RPH. Pada RPH ayam tingginya hasil uji pada RPH ayam disebabkan oleh ketidakefektifan unit IPAL sehinga perlu ditinjau tentang sistem yang digunakan pada IPAL. Hasil uji air limbah RPH ayam lebih tinggi dibandingkan dengan air limbah RPH sapi disebabkan oleh karena RPH sapi sudah mengalami pengenceran oleh aliran air sungai yang mengalir melalui drainase disekitar RPH selain itu diduga disebabkan oleh protein dalam ransum ayam boiler lebih tinggi dari pada ransum pada protein sapi. 
- Angka Lempeng Total (ALT) air limbah RPH sapi rerata hasil 284004 x $10^{4} \mathrm{koloni} / \mathrm{ml}$, dan mengandung mikroba dengan jenis E. coli dan Salmonella. Sedangkan air limbah RPH ayam kandungan ALT rerata 101596 x $10^{5} \mathrm{koloni} / \mathrm{ml}$ dan mengandung kuman dengan jenis E.coli, Pseudomos aeruginosa dan Klebsiella pneumoniae.

\section{DAFTAR PUSTAKA}

Amrullah, I.K. 2002. Seri Beternak Mandiri Nutrisi Ayam Broiler. Lembaga Satu Gunungbudi KPP IPB. Bogor.

Arnia dan Warganegara. 2012. Identifikasi Kontaminasi Bakteri coliform pada Daging sapi Segar yang Dijual di Pasar Sekitar Kota Bandar Lampung. Majority 26 (4) 101-108. ISSN 2337-3776.

Bazrafshan, E., F. Kord Mustafapour, M. Farzadkia, K.A. Ownagh, A.H. Mahvi. 2012. Slaughter house Wastewater Treatment by Combined Chemical Coagulation and Electrocoagulation Process. Plos ONE 7 (6): e40108. Doi:10.1371/journal.pone.0040108.

Darmayasa, I.G.B. 2008. Isolasi dan Identifikasi Bakteri Pendegradasi Lipid (lemak) pada Beberapa Tempat Pembuangan Limbah dan Estuari DAM Denpasar. Jurnal Bumi Lestari, Vol. 8 No. 2, Agustus 2008. Hal 122-127.

Dinas Peternakan dan Kesehatan Hewan. 2014. Kumpulan Data Kesehatan masyarakat Veteriner, Dinas Peternakan dan Kesehatan Hewan Provinsi Nusa Tenggara Barat.

Effendi, H. 2003. Telaah kualitas air bagi pengelola sumber daya dan lingkungan perairan. Yogyakarta. Kanisius.

Herlambang, A. 2006. Pencemaran air dan strategi penanggulanganya. JAI Vol 2, No.1.

Kementerian Pertanian. 2010. Peraturan Menteri Pertanian Republik Indonesia No. 13/permentan/OT.140/I/2010 Tentang Persyaratan Rumah Potong Hewan Ruminansia dan Unit Penanganan daging (meat cutting plant).

Kementerian Lingkungan Hidup. 2014. Peraturan Menteri Lingkungan Hidup No. 5 Tahun 2014 Tentang Baku Mutu Air Limbah.

Kobya, M., E. Sentruk, C. Aydiner and E. Demirbas. 2006. Treatment of potato chips manufacturing waste water by electroagulation. Desalination Vol. 190: 201-211.

Kundu, P., A. Dabsarkar, S. Mukherjee. 2013. Treatment of Slaughter House Wastewater in a sequencing Batch Reactor, Performance evaluation and Biodegradation Kinetics. Hindawi Publishing Corporation, BioMed Research International Article ID134872, II pages.

Parakkasi, A. 1999. Ilmu Nutrisi dan Makanan Ternak Ruminansia. UI Press.

Putri A.R., G. Samudro, D.S. Handayani. 2013. Penentuan Rasio BOD/ COD Optimal Pada Reaktor Aerob, Fakultatif dan Anaerob. Jurnal Teknik Lingkungan Vol. 2 No.1.

Parasmita, B.N., W. Oktiawan, M. Hadiwidodo. 2012. Studi Pengaruh Waktu Tinggal Terhadap Penyisihan Parameter BOD5, COD dan TSS Lindi Menggunakan Biofilter Secara Anaerob-Aerob. E journal Undip.

Roniadi A., A.P.M. Tarigan, P.N. Zaid. 2013. Evaluasi Pengolahan Air Limbah Rumah Potong Hewan di Kelurahan Maba Hilir Kecamatan Medan Deli, Universitas Sumatera Utara, Medan. Jurnal.usu.ac.id Vol 2 No 1.
Said, N.I. dan Satmoko, Y. 2006. Rancang Bangun Instalasi Pengolahan Air Limbah Rumah Potong Hewan Ayam dengan Proses Biofilter. JAI Vol. 2, No. 1.

Suardana, I.W. 2007. Karakterisasi Limbah Cair Rumah Potong Hewan Pesanggrahan. Animal Production, Mei 2007, hal. 116-122. ISSN 1411 - 2027.

Susanto H., Budijono, M. Hasbi. 2013. Peningkatan Degradasi Polutan organik Air Limbah Rumah Potong Hewan dengan Proses Biofilter Kombinasi AnaerobAerob Bermedia Botol Plastik Berisikan PotonganPotongan Plastik Untuk Media Hidup Ikan Budidaya. Fakultas Perikanan dan Ilmu Kelautan UNRI. Pekanbaru.

Syahrurachman, A., A. Chatim, W.K.A. Soebandrio, A. Kariniawati, A.U.S. Santoso, H.B.M. Hasrul. 1994. Mikrobiologi Kedokteran. Binarupa Aksara.

Tantrip, R. dan Thungkao, S. 2011. Isolation Proteolytic, Lipolytic, and Bioemulsifying Bacteria for Improvement of the Aerobic Treatment of Poultry Processing Wastewater. African Journal of Microbiologi Research Vol. 5 (30)

Widya N., W. Budiarsa, M.S. Mahendra. 2009. Studi Pengaruh Air Limbah Pemotongan Hewan dan Unggas Terhadap Kualitas Air Sungai Subak PakelI desa Darmasaba Kecamatan Abiansemal Kabupaten Badung. ISSN: 1907-5626 